\title{
URGENSI PANCASILA SEBAGAI IDEOLOGI NEGARA NURUL SYADILAH
}

nurulsyahdilla26@gmail.com

20220133

\section{STIE AKBP KBP PADANG}

\section{A. PENDAhULUAN}

Ideologi Merupakan Sebuah Konsep Yang Fundamental Dan Aktual Dalam

Sebuah Negara. Fundamental Karena Hampir Semua Bangsa Dalam Kehidupannya Tidak Dapat Dilepaskan Dari Pengaruh Ideologi. Aktual, Karena Kajian Ideologi Tidak Pernah Usang Dan Ketinggalan Jaman. Harus Disadari Bahwa Tanpa Ideologi Yang Mantap Dan Berakar Pada Nilai-Nilai Budaya Sendiri, Suatu Bangsa Akan Mengalami Hambatan Dalam Mencapai Cita-Citanya.

Menurut Syafiie (2001:61), Ideologi Adalah "Sistem Pedoman Hidup Yang Menjadi Cita-Cita Untuk Dicapai Oleh Sebagian Besar Individu Dalam Masyarakat Yang Bersifat Khusus, Disusun Secara Sadar Oleh Tokoh Pemikir Negara Serta Kemudian Menyebarluaskannya Dengan Resmi".

Menurut Sutrisno (2006:24), Istilah "Ideologi Pertama Diciptakan Oleh

Desstutt De Tracy Tahun 1976 Di Perancis, Telah Terjadi Pergeseran Arti Begitu Rupa Sehingga Ideologi Dewasa Ini Merupakan Istilah Dengan Pengertian Yang Kompleks".

Menurut Syamsudin (2009:98), Ideologi Adalah Ideologi Secara Etimologis Ideologi Berasal Dari Kata Idea Dan Logosidea Berarti Gagasan, Konsep, Pengertian Dasar, Cita-Cita. Kata Idea Berasal Dari Bahasa Yunani Ideos Yang Berarti Bentuk Atau Idean Yang Berarti Melihat, 
Sedangkan Logos Berarti Ilmu. Dengan Demikian Ideologi Berarti Ilmu PengertianPengertian Dasar Ide-Ide (The Scince Of Ideas) Atau Ajaran Tentang PengertianPengertian Dasar. Ide Dapat Di Artikan Cita-Cita Yang Bersifat Tetap Dan Yang Harus Dicapai".

Berarti Cita-Cita Ini Pada Hakikatnya Merupakan Dasar Pandangan Atau Faham Yang Diyakini Kebenarannya. Ideologi Diharapkan Dapat Memberikan Tuntunan Atau Pedoman Perilaku Bagi Warga Masyarakat Dalam Kehidupan Bernegara Dan Berbangsa. Inilah Arti Pentingnya Sebuah Ideologi Bagi Bangsa Dan Negara.

Menurut Syamsudin (2009:98), Ideologi Adalah "Keseluruhan Prinsip Atau Norma Yang Berlaku Dalam Suatu Masyarakat Yang Meliputi Berbagai Aspek, Seperti Sosial Politik, Ekonomi, Budaya, Dan Hankam”.

Menurut W.White Sebagaimana Dikutip Kansil (2005:27), Ideologi Ialah Soal Cita-Cita Mengenai Berbagai Macam Masalah Politik Dan Ekonomi Filsafat Sosial Yang Sering Dilaksanakan Bagi Suatu Rencana Yang Sistematis Tentang Cita-Cita Yang Dijalankan Oleh Kelompok Atau Lapisan Masyarakat.

Dengan Demikian Ideologi Merupakan Alat Pengikat Yang Baik Karena Didasarkan Pada Pemikiran Yang Menyatakan Bahwa Jika Persatuan Sudah Terwujud Maka Alat Pengikat Sudah Tidak Diperlukan.

Kenyataan Menunjukkan Bahwa Kebersamaan Masyarakat Sebenarnya Dibangun Diatas Keanekaragamaan (Budaya, Etnis, Bahasa, Agama Dan Sebagainya), Sehingga Perpecahan Merupakan Benih Yang Subur Dan Siap Meledak Setiap Saat. Mengingat Pentingnya Ideologi Bagi Sebuah Negara, Maka Pembinaan Secara Terus Menerus Agar Ideologi Yang Diterimanya Semakin Mengakar Dan Pada Gilirannya Mampu Membimbing Masyarakat Menuju Pemikiran Yang Relatif Sama. Upaya Memahami Ideologi Bagi Suatu Bangsa Juga Dapat Dilakukan Melalui Pemahaman Tentang Fungsi Ideologi Yang Dianut Oleh Suatu Negara. 


\section{B. PEMBAHASAN}

Negara Indonesia Telah Memiliki Suatu Ideologi Negara Bernama Pancasila. Pancasila Menurut Darmodhiharjo (1991:230), Yaitu:

Pancasila Merupakan "Lima Dasar Atau Lima Asas Adalah Nama Dari Dasar Negara Republik Indonesia". Istilah Pancasila Sudah Dikenal Sejak Jaman Majapahit Pada Abad XIV, Yaitu Terdapat Dalam Buku Negarakertagama Karangan Prapanca Dan Buku Sutasoma Karangan Tantular.

Ditinjau Dari Sejarahnya Istilah "Pancasila" Pertama Kali Disampaikan Oleh Ir.Soekarno Pada Saat Mengusulkan Dasar Negara Indonesia. Selanjutnya, Pancasila Dikenal Saat Ini Adalah Ideologi Negara Indonesia Yang Tertuang Di Dalam Pembukaan UUD 1945 Pada Alinea Keempat. Hakikat Pancasila Adalah Pandangan Hidup Bangsa Dan Sebagai Dasar Negara Indonesia. Pancasila Sebagai Dasar Negara Dan Pandangan Hidup Memiliki Status Yang Resmi Yaitu Tercantum Pada Alinea IV Dalam Undang-Undang 1945.

Menurut Widjaja (1995:72), “Pancasila Sebagai Pandangan Hidup Bangsa Yang Berisikan Konsep Dasar Mengenai Kehidupan Yang Dicita-Citakan Dan Pikiran-Pikiran Serta Gagasan-Gagasan Yang Dianggap Baik Oleh Bangsa”. Pandangan Hidup Merupakan Kristalisasi Nilai-Nilai Yang Diyakini Kebenaran, Ketepatan, Dan Kemanfaatannya. Itulah Yang Menimbulkan Tekad Untuk Mewujudkan Dalam Bentuk Sikap, Tingkah Laku, Dan Perbuatan.

Pancasila Merupakan Jiwa Seluruh Rakyat Indonesia, Kepribadian Bangsa Indonesia, Pandangan Hidup Bangsa Indonesia Dan Pancasila Menjadi Tujuan Hidup Bangsa Indonesia. Pancasila Bagi Bangsa Indonesia Merupakan Pandangan Hidup Kesadaran Dan Cita-Cita Moral Yang Meliputi Kejiwaan Dan Watak Yang Sudah Berurat Akar Dalam Kebudayaan Bangsa Indonesia. Pancasila Sudah Mengakar Dalam Kepribadian Bangsa, Maka Dapat Diterima Sebagai Dasar Negara Yang Mengatur Hidup Ketatanegaraan.

Menurut Kaelan (2009: 46)

Pancasila Yaitu Mempunyai Peranan Dan Fungsi Dalam Bermasyarakat, Berbangsa Dan Bernegara, Seperti Pancasila Sebagai Jati Diri Bangsa, Pancasila Sebagai Ideologi Bangsa Dan Negara Indonesia, Pancasila Sebagai Dasar Filsafat Negara, Pancasila Sebagai Asas Persatuan Dan Kesatuan Bangsa Indonesia.

Untuk Melaksanakan Masyarakat Pancasila Perlu Usaha Dilakukan Secara Berencana Dan Terarah. Tujuanya Agar Pancasila Sungguh-Sungguh Dihayati Dan 
Diamalkan Segenap Warga Negara Yang Diharapkan Pembinaan Masyarakat Indonesia Agar Menjadi Insan Pancasila Dan Pembangunan Bangsa Untuk Mewujudkan Masyarakat Pancasila. Pembinaan Insan Pancasila Dapat Melalui Jalur Pendidikan Maupun Masyarakat Atau Sebuah Organisasi Masyarakat.

Pancasila Sebagai Dasar Negara, Maka Mengamalkan Dan Mengamankan Pancasila Sebagai Dasar Negara Mempunyai Sifat Impreatif Dan Memaksa, Artinya Setiap Warga Negara Indonesia Harus Tunduk Dan Taat Kepadanya. Artinya Siapa Saja Yang Melanggar Hukum Harus Ditindak Menurut Hukum Yang Berlaku Di Negara Indonesia.

\section{Menurut Kansil (2005: 28),}

Pengamalan Pancasila Adalah Pengalaman Pancasila Sebagai Welltaunschuang Yaitu Pelaksanaan Pancasila Dalam Kehidupan Sehari-Hari Tidak Disertai Sanksi-Sanksi Hukum Tetapi Mempunyai Sifat Mengikat, Artinya Setiap Masyarakat Indonesia Terikat Dengan Cita-Cita Yang Terkandung Didalamnya Sepanjang Tidak Melanggar Peraturan Perundang-Undangan Yang Berlaku.

Dapat Disimpulkan Bahwa Pancasila Harus Menjadi Pedoman Dan Arah Hidup Manusia Indonesia Termasuk Partai Politik, Lembaga Swadaya Masyarakat Dan Organisasi Masyarakat.

Organisasi Masyarakat Telah Diatur Dalam UUD No.17 Tahun 2013, Di Jelaskan Dalam Pasal 1 Ayat (1) Yaitu Ormas Adalah Organisasi Yang Didirikan Dan Dibentuk Oleh Masyarakat Secara Sukarela Berdasarkan Kesamaan Aspirasi, Kehendak, Kebutuhan, Kepentingan, Kegiatan, Dan Tujuan Untuk Berpartisipasi Dalam Pembangunan Demi Tercapainya Tujuan Negara Kesatuan Republik Indonesia Yang Berdasarkan Pancasila. Bahwa Ormas Berasaskan Tidak Bertentangan Dengan Pancasila Dan Undang-Undang Dasar Negara Republik Indonesia Tahun 1945. Ormas Dapat Mencantumkan Ciri Tertentu Yang Mencerminkan Kehendak Dan CitaCita Ormas Tidak Bertentangan Dengan Pancasila Dan Undang-Undang Dasar Negara. Pengaturan Tersebut Diharapkan Dapat Menjadi Aturan Yang Lebih Baik Dan Memberikan Manfaat Kepada Sistem Kehidupan Bermasyarakat, Berbangsa, Dan Bernegara.

Thionghoa Merupakan Salah Satu Etnis Yang Ada Di Indonesia, Berbagai Organisasi Masyarakat Yang Didirikan Oleh Etnis Thionghoa, Yang Dilakukan Dalam Kegiatan Sosial. 
Tujuan Ormas Dalam Undang-Undang Dasar No.17 Tahun 2013

Pasal 5 Yaitu,

Meningkatkan Partisipasi Dan Keberdayaan Masyarakat, Memberikan

Pelayanan Kepada Masyarakat, Menjaga Nilai Agama Dan Kepercayaan

Terhadap Tuhan Yang Maha Esa, Melestarikan Dan Memelihara Norma, Nilai, Moral, Etika, Dan Budaya Yang Hidup Dalam Masyarakat, Melestarikan Sumber Daya Alam Dan Lingkungan Hidup, Mengembangkan Kesetiakawanan Sosial, Gotong Royong, Dan Toleransi Dalam Kehidupan Bermasyarakat, Menjaga, Memelihara, Dan Memperkuat Persatuan Dan Kesatuan Bangsa, Dan Mewujudkan Tujuan Negara.

Sesuai Tujuan Ormas Yang Telah Disebutkan Di Atas, Berbagai Ormas Thionghoa Yang Ada Seperti PITI, PMS, Himpunan Fuqing, Dan Sebagainya Selaras Dengan Yang Telah Ditentukan. Dalam Pergerakan Organisasi Masyarakat Thionghoa Di Surakarta Merupakan Sebuah Wadah Yang Melakukan Kegiatan Dalam Kemasyarakatan Untuk Membantu Sesama.

Perkumpulan Masyarakat Surakarta (PMS) Merupakan Salah Satu Organisasi Etnis Thionghoa Yang Ada Di Surakarta, Bertujuan Untuk Mengemban Misi Sosial Yaitu Sembilan Misi Diantaranya Memberikan Bantuan Terhadap Penyelenggaraan Pernikahan, Memberi Pertolongan Bantuan Kesusahan, Sosial, Menyemarakkan Kesenian Tonil, Musik Dan Olahraga. Kemudian Kesehatan Dengan Membuat Poliklinik, Kantor Buruh, Kantor Akuntan Hingga Penerangan Untuk Segala Urusan Serta Pendidikan.

Ada Banyak Ormas Di Indonesia Berjalan Sesuai Dengan Aturan. Namun Tidak Sedikit Melakukan Penyimpangan Yang Terjadi Didalam Sebuah Organisasi Atau Dapat Diletakan Tidak Sesuai Dengan Nilai-Nilai Pancasila. Realita Yang Terjadi Adanya Organisasi Masyarakat Yang Tidak Sesuai Dengan Nilai-Nilai Pancasila. Hal Tersebut Muncul Dalam Media Online Yaitu Pada Kabar Tribun.News.Com (Nopember 2013), Misalnya FPI Terlibat Bentrok Dengan Warga Terjadi Di Dusun Gowah, Desa Blimbing, Kecamatan Paciran, Kabupaten Lamongan, Jawa Timur. Sebelumnya Warga Di Kendal, Jawa Tengah, Juga Terlibat Bentrok Dengan FPI Yang Melakukan Razia Dalam Bulan Puasa Lalu. Akibat Bentrok Ini, Seorang Warga Pengendara Sepeda Motor Tewas Ditabrak Mobil Anggota FPI Yang Panik Saat Dikejar Penduduk. Kejadian Tersebut Disebabkan Karena Para Anggota FPI Main Hakim Sendiri Tanpa Memperdulikan Dan Menghormati Hak-Hak Orang Lain. Penanaman Nilai-Nilai Pancasila Khususnya Nilai Persatuan Indonesia Dirasa Perlu Untuk Dilakukan Bukan Hanya Sekedar Teori Dan Formalitas Tetapi Pelaksanaannya Dalam Kegiatan-Kegiatan Pada Organisasi. Hal Ini Selaras Dengan 
Ppkn Yang Menjadi Mata Pelajaran Wajib Bagi Peserta Didik. Ppkn Mempunyai Peranan Penting Dalam Membentuk Karakter Dan Menjadikan Manusia Yang Memiliki Rasa Kebangsaan. Sesuai Dengan Visi Dan Misi Ppkn Yaitu Menanamkan Komitmen Yang Kuat Dan Konsisten Terhadap Prinsip Dan Semangat Kebangsaan Dalam Kehidupan Bermasyarakat Dan Berbangsa, Dan Bernegara Yang Berdasarkan Pancasila Dan Undang-Undang Dasar 1945 Guna Memberikan Pemahaman Mendalam Tentang Negara Kesatuan Republikindonesia. Misi Pkn Ialah Menghindarkan Indonesia Dari Sistem Pemerintah Otoriter Yang Memasung HakHak Warga Negara Untuk Menjalankan Prinsip-Prinsip Demokrasi Dalam Kehidupan Bermasyarakat, Berbangsa Dan Bernegara (BSNP, 2006:155)

Hal Tersebut Bertujuan Untuk Memupuk Sikap Dan Perilaku Yang Sesuai Dengan Nilai-Nilai Pancasila. Adanya Arah Untuk Mendukung Persatuan Bangsa Dan Bersikap Atau Bertindak Adil Dalam Mengatasi Segmentasi Atau Promodialisme Sempit Dengan Jiwa Dan Semangat "Bhineka Tunggal Ika" Yaitu Bersatu Dalam Perbedaan Dan Berbeda-Beda Dalam Satu Jiwa.

Muatan-Muatan Ppkn Diharapkan Memahami Dan Menghayati Pelaksanaan Pancasila Dan Undang-Undang Dasar 1945 Yang Berjiwa Pancasila. Menguasai Pemahaman Tentang Beragram Masalah Dasar Kehidupan Bermasyarakat, Berbangsa Dan Bernegara Yang Hendak Diatasi Dengan Penerapan Yang Berlandaskan Pancasila. Dengan Demikian Tujuan Ormas Dapat Tercapai Diantaranya Meningkatkan Partisipasi, Keberdayaan Masyarakat, Memberikan Pelayanan Kepada Masyarakat, Menjaga Nilai Agama, Kepercayaan Terhadap Tuhan Yang Maha Esa, Melestarikan, Memelihara Norma, Nilai, Moral, Etika, Dan Budaya Yang Hidup Dalam Masyarakat, Melestarikan Sumber Daya Alam Dan Lingkungan Hidup. Selain Itu Tujuan Ormas Untuk Mengembangkan Kesetiakawanan Sosial, Gotong Royong, Toleransi Dalam Kehidupan Bermasyarakat, Menjaga, Memelihara, Dan Memperkuat Persatuan Dan Kesatuan Bangsa, Serta Mewujudkan Tujuan Negara. Berdasarkan Fenomena Dan Hasil Pengamatan Menegaskan Masih Adanya Organisasi Masyarakat Yang Tidak Sesuai Dengan Nilai-Nilai Pancasila Khususnya Nilai Persatuan Indonesia. Hal Tersebut Mendorong Peneliti Untuk Melakukan Penelitian "Penanaman Nilai-Nilai Pancasila Khususnya Nilai Persatuan Indonesia Pada Etnis Thionghoa (Studi Kasus Organisasi Perkumpulan Masyarakat Surakarta Tahun 2014). 


\section{PENUTUP}

Urgensi Pendidikan Pancasila Dapat Memperkokoh Jiwa Kebangsaan Mahasiswasehingga Menjadi Dorongan Pokok Dan Penunjuk Jalan Bagi Calon Pemegang Kepemimpinan Bangsa Di Berbagai Bidang Dan Tingkatan. Calon Generasi Kepemimpinan Bangsa Tidak Mudah Terpengaruh Oleh Paham-Paham Asing Yang Dapat Mendorong Untuk Tidak Dijalankannya Nilai-Nilai Pancasila. Pentingnya Pendidikan Pancasila Diperguruan Tinggi Adalah Untuk Menjawab Tantangan Dunia Dengan Mempersiapkan Warga Negara Yang Menpunyai Pengetahuan, Pemahaman, Penghargaan, Penghayatan, Komitmen Dan Pola Pengamalan Pancasila. Untuk Melahirkan Lulusan Yang Menjadi Kekuatan Inti Pembangunan, Generasi Muda Bangsa Dalam Setiap Tingkatan Lembaga-Lembaga Negara, Badan-Badan Negara, Lembaga Daerah, Lembaga Infrastruktur Politik, Dan Lembaga Lain Menjunjung Tinggi Nilai Nilai Luhur Pancasila.

\section{DAFTAR PUSTAKA}

Darmini Roza Dan Laurensius Arliman S Peran Pemerintah Daerah Di Dalam Melindungi Hak Anak Di Indonesia, Masalah-Masalah Hukum, Volume 47, Nomor 1, 2018.

Laurensius Arliman S, Komnas HAM Dan Perlindungan Anak Pelaku Tindak Pidana, Deepublish, Yogyakarta, 2015.

Laurensius Arliman S, Penguatan Perlindungan Anak Dari Tindakan Human Trafficking Di Daerah Perbatasan Indonesia, Jurnal Selat, Volume 4, Nomor 1, 2016.

Laurensius Arliman S, Problematika Dan Solusi Pemenuhan Perlindungan Hak Anak Sebagai Tersangka Tindak Pidana Di Satlantas Polresta Pariaman, Justicia Islamica, Volume 13, Nomor 2, 2016.

Laurensius Arliman S, Pelaksanaan Perlindungan Anak Yang Tereksploitasi Secara Ekonomi Oleh Pemerintah Kota Padang, Veritas Et Justitia, Volume 2, Nomor 1, 2016.

Laurensius Arliman S, Kedudukan Ketetapan MPR Dalam Hierarki Peraturan Perundang-Undangan Di Indonesia, Lex Jurnalica, Volume 13, Nomor 3, 2016

Laurensius Arliman S, Komnas Perempuan Sebagai State Auxialiary Bodies Dalam Penegakan Ham Perempuan Indonesia, Justicia Islamica, Volume 14, Nomor 2, 2017. 
Laurensius Arliman S, Peranan Pers Untuk Mewujudkan Perlindungan Anak Berkelanjutan Di Indonesia, Jurnal Ilmu Hukum Tambun Bungai, Volume 2, Nomor 2, 2017.

Laurensius Arliman S, Mewujudkan Penegakan Hukum Yang Baik Untuk Mewujudkan Indonesia Sebagai Negara Hukum, Jurnal Hukum Doctrinal, Volume 2, Nomor 2, 2017.

Laurensius Arliman S, Participation Non-Governmental Organization In Protecting Child Rights In The Area Of Social Conflict, The 1st Ushuluddin And Islamic Thought International Conference (Usicon), Volume 1, 2017.

Laurensius Arliman S, Partisipasi Masyarakat Dalam Pembentukan Perundang Undangan Untuk Mewujudkan Negara Kesejahteraan Indonesia, Jurnal Politik Pemerintahan Dharma Praja, Volume 10, Nomor 1, 2017, Https://Doi.Org/10.33701/Jppdp.V10i1.379.

Laurensius Arliman S, Peran Komisi Perlindungan Anak Indonesia Untuk Mewujudkan Perlindungan Anak, Jurnal Respublica Volume 17, Nomor 2, 2018.

Laurensius Arliman S, Menjerat Pelaku Penyuruh Pengrusakan Barang Milik Orang Lain Dengan Mempertimbangkan Asas Fungsi Sosial, Jurnal Gagasan Hukum, Volume 1, Nomor 1, 2019.

Laurensius Arliman S, Ilmu Perundang-Undangan Yang Baik Untuk Negara Indonesia, Deepublish, Yogyakarta, 2019.

Laurensius Arliman S, Isdal Veri, Gustiwarni, Elfitrayenti, Ade Sakurawati, Yasri, Pengaruh Karakteristik Individu, Perlindungan Hak Perempuan Terhadap Kualitas Pelayanan Komnas Perempuan Dengan Kompetensi Sumber Daya Manusia Sebagai Variabel Mediasi, Jurnal Menara Ekonomi: Penelitian Dan Kajian Ilmiah Bidang Ekonomi, Volume 6, Nomor 2, 2020.

Laurensius Arliman S, Pendidikan Kewarganegaraan, Deepublish, Yogyakarta, 2020.

Laurensius Arliman S, Makna Keuangan Negara Dalam Pasal Pasal 23 E UndangUndang Dasar 1945, Jurnal Lex Librum, Volume 6, Nomor 2 Juni 2020, Http://Dx.Doi.Org/10.46839/Llijh.V6i2.151.

Laurensius Arliman S, Kedudukan Lembaga Negara Independen Di Indonesia Untuk Mencapai Tujuan Negara Hukum, Kertha Semaya Journal Ilmu Hukum, Volume 8, Nomor 7, 2020. 
Laurensius Arliman S, Pelaksanaan Assesment Oleh Polres Kepulauan Mentawai Sebagai Bentuk Pelaksanaan Rehabilitasi Bagi Pecandu Dan Korban Penyalahgunaan Narkotika, Jurnal Muhakkamah, Volume 5, Nomor 1, 2020.

Laurensius Arliman S, Aswandi Aswandi, Firgi Nurdiansyah, Laxmy Defilah, Nova Sari Yudistia, Ni Putu Eka, Viona Putri, Zakia Zakia, Ernita Arief, Prinsip, Mekanisme Dan Bentuk Pelayanan Informasi Kepada Publik Oleh Direktorat Jenderal Pajak, Volume 17, No Nomor, 2020.

Larensius Arliman S, Koordinasi PT. Pegadaian (Persero) Dengan Direktorat Reserse Narkoba Polda Sumbar Dalam Penimbangan Barang Bukti Penyalahgunaan Narkotika, UIR Law Review, Volume 4, Nomor 2, 2020, Https://Doi.Org/10.25299/Uirlrev.2020.Vol4(1).3779.

Laurensius Arliman S, Tantangan Pendidikan Kewarganegaraan Pada Revolusi 4.0, Ensiklopedia Sosial Review, Volume 2, Nomor 3, 2020.

Muhammad Afif Dan Laurensius Arliman S, Protection Of Children's Rights Of The Islamic And Constitutional Law Perspective Of The Republic Of Indonesia, Proceeding: Internasional Conference On Humanity, Law And Sharia (Ichlash), Volume 1, Nomor 2, 2020 .

Otong Rosadi Danlaurensius Arliman S, Urgensi Pengaturan Badan Pembinaan Idelogipancasila Berdasarkan Undang-Undang Sebagai State Auxiliary Bodies Yang Merawat Pancasila Dalam Perspektif Hak Asasi Manusia, Prosiding Konferensi Nasional Hak Asasi Manusia, Kebudayaan Dan Tujuan Pembangunan Berkelanjutan Indonesia Pada Masa Pandemi Covid-19: Tantangan Untuk Keilmuan Hukum Dan Sosial Volume 1, Universitas Pancasila, Jakarta, 2020. 